\title{
The Visualization and Meaning of Logo and Slogan Used by The Ministry of Marine and Fisheries
}

\author{
Tusana Nurul Safaah ${ }^{1}$, Andayani ${ }^{2}$, Nugraaheni Eko Wardani ${ }^{3}$ \\ ${ }^{123}$ Universitas Sebelas Maret, Surakarta \\ ${ }^{1}$ tusananurul@student.uns.ac.id, ${ }^{2}$ bu anda@yahoo.co.id, \\ 3nugraheniekowardani_99@staff.uns.ac.id
}

\begin{abstract}
The research on the visualization and meaning of slogans in Indonesia is very important to be carried out so that we know the meaning and provide implementation of these slogans. This study aims to identify the visualization, meaning, and characteristics of the slogan in the Indonesian Ministry of Maritime Affairs and Fisheries. The method used in this research is descriptive qualitative with content analysis techniques and use the principles of The Good Eye from Gillian Rose's. The main study object of this research is the slogans used by the work unit of the Ministry of Maritime Affairs and Fisheries, which are spread in several places. These slogans are appropriate and need to be investigated because they use various Indonesian languages in terms of words, sentences and the words contained in them. The results of this study are (1) the logos and slogans used in the work unit of the Ministry of Maritime Affairs and Fisheries of Republic of Indonesia have the objective to invite people to care about the marine environment; (2) the slogans have a unique language dan visualization in each work unit of the Indonesian Ministry of Maritime Affairs and Fisheries.
\end{abstract}

Keywords: Visualization, Study of meaning, slogan, linguistics

\section{Introduction}

The slogan almost has the same strategy as advertising in the Community. Slogans and advertisements are one form of mass communication that not only functions as a promotional tool to offer goods and services, but also experiences an expansion of functions as a tool to embed symbolic meaning through language and visualization in advertising messages. In addition, advertising is a portrait of reality in society so that it can spread social, cultural, political, and so on[1]. The slogan created by an institution must have a good purpose for the community. One of the relevant objectives is to provide good information and education about life behavior. The slogan also includes the reality and habits of people's lives.

Visualization can be done as communication through two-dimensional visual language through images, symbols, icons, colors. Visualization can be given as a visual language, where this language is a nonverbal language intended to communicate an idea, debate in answering seniors and design through visual rules that can be translated and accounted[2]. Meanwhile, visualization can be considered as the result of visual thinking, namely imaginative thinking using visual language. In the slogan, whatever message is made, the most important thing is what the reader do with the message delivered, where this can determine success. 
In a slogan has a message to be conveyed to the public. The message is implanted through a series of codes and visual images used in the slogan[3]. Activities to interpret the slogan certainly differ depending on the viewpoint of the community. Sometimes the message of the slogan is made so unique as a form of creativity of the creator, which is just a representation of a phenomenon that must be interpreted by the audience. However, the slogan making agency namely the Ministry of Maritime Affairs and Fisheries of the Republic of Indonesia has a good goal which is to develop a culture of people to love eating fish.

In the other side, the study of meaning in the slogan is a phenomenon of language use that is different from the phenomenon of other language use. Meaning is a symptom in utterance, while information is a symptom outside utterance. In addition to information, the intent is also outside the utterance. The difference is that information is something outside the utterance seen in terms of the object or thing being spoken, while the intent is seen in terms of the speaker, the person speaking, or the subject. The meaning of a sentence has a relationship between language and the outer world that has been mutually agreed upon by language users so that they can understand each other[4]. The definition above is known that there are three main elements included in it, that are: (1) meaning is the result of the relationship between language and the outer world; (2) relationship determination occurs because of the agreement of the users; (3) the embodiment of meaning can be used to convey information so that it able mutually understood[5].

The meaning given to the language written or spoken by someone is related to the purpose that are expected has its own meaning to the public or community. Language as a means of communication and a tool for social interaction has a very important role in life. The role of language as a communication tool is as a symbol or form of utterance and meaning that can be understood. The conveying of meanings in the form of language symbols is an expression of someone to convey the ideas. The agreement between the language users in understanding each other's intended meaning is the content of the form or symbol of language. In other words, various meanings can be obtained in the language, both in written and spoken languages.

\section{Method}

Penelitian This study was descriptive qualitative research with content analysis strategy which analyzing meaning content of language and visualization in the slogan used within the Ministry of Maritime and Fisheries Affairs. In visualization of slogan, In Gillian Rose's visual methodology, the analysis process is carried out using the principles of The Good Eye and the Monaco scheme. In the principle of The Good Eye, a visual object is examined based on content, which is related to the contents of a visual object. The process can be done by taking pieces of the image on a moving visual object and then analyzing it. This study was not bound by the place of research, because the research object was texts, which is the slogan used within the Ministry of Maritime and Fisheries Affairs. This descriptive study obtained descriptive data in the form of written or oral words derived from the manuscript or the person being observed[6]. This qualitative research is a process of scientific research that is intended to understand human problems in a social context by creating descriptions that are presented in a general and complex,reported the observation in detail of the resources, as well as carried out by natural setting without any intervention from the researcher[7]. 


\section{Result and Discussion}

Visualization in the slogan used by the Ministry of Maritime Affairs and Fisheries of the Republic Indonesia has a wide variety of variations. The slogan has a uniqueness and a message that will be conveyed to the people of Indonesia. This institution has a strategy to influence the public by visualizing colored slogans. The visualization is used to give enthusiasm and youthful spirit that this ministry is able to develop well and can work together with the people of Indonesia. One example is the slogan to encourage people to love eating fish and caring for the Indonesian sea from Sabang to Merauke.

The Ministry of Maritime Affairs and Fisheries of the Republic of Indonesia has a good union with its employees. The slogan made by this ministry also has the advantage to provide enthusiasm and main guidelines when serving the community. This institution also has principles to create healthy marine and fishery products, which have high quality, are safe if consumed by the community, and have a high level of trust. Therefore, the visualization produced in the form of words that are Smart, Fast, and professional service with a pink background and words that are colored in red, which means firm, brave, disciplined, and have a strong character.

Language is the main object of the linguistic study. Language used as an object is a language used by humans to communicate[8]. Human language is a language that can be learned because the language has a system so that the system that regulates the use of construction-building constituents in language, for example, is in the system of sound. The sounds are free symbols that can build constructions with different forms and meanings. The usage of sound symbol system is approved by the user community and can be learned so that it can be used as a means of communication among the speaker community.

The others example, The Indonesian Ministry of Maritime and Fisheries Affairs has work programs and visions that must be conveyed to the public through language with specific slogans in each work unit. This ministry has a slogan that is also used as a mission, that is "Sektor Kelautan dan Perikanan Indonesia harus 3M yakni Mandiri, Maju, dan Kuat" Indonesian Maritime and Fisheries Sector, must be Independent, Advanced, and Strong. Those words are a good vision in placing the marine and fisheries sector as one of the mainstay sectors that is able to deliver the Indonesian nation to become an independent country by utilizing natural resources from the sea, advanced by maximizing the maritime management, and strong in facing challenges in the modern era. The Ministry of Maritime and Fisheries Affairs is also committed to making Indonesia emerge from regional and international economic crises.

Slogan is a phrase, words, sentences or motto used by individuals and groups in various contexts such as politics, commercial, religion, education, environment, etc., as an expression of an idea and purpose that is easy to remember that is suggestive and build individual aware. The slogans at the Indonesian Ministry of Maritime and Fisheries Affairs also represent environmental connections and have a motive to provide education and suggestions to the public to take action in accordance with the Ministry of Maritime and Fisheries Affairs's expectations. The slogan is also used as a work unit's identity as well as a vision that is relevant to the management and improvement of Indonesia's marine resources.

The various forms of slogan can be interpreted as a series of words or short sentences that are generally very interesting and easy to remember by many people[9]. Slogans are used to inform or convey information. The sentence in the slogan is an interesting sentence, striking and easy to remember to explain the ideology of an organization, class, political party, etc. Slogans are short and interesting sentences so they can stick to everyone's memories[10]. Slogan sentences must be short so that they are easily remembered by people. The usual 
slogan is presented in the form of phrases, clauses, or sentences. In the slogans used by the work unit in the Ministry of Maritime and Fisheries Affairs has two main meanings, which are to improve the welfare of the fish farmers and to realize the preservation of aquaculture resources and to encourage the community to likes to eat fish. This can also be seen as the examples below.
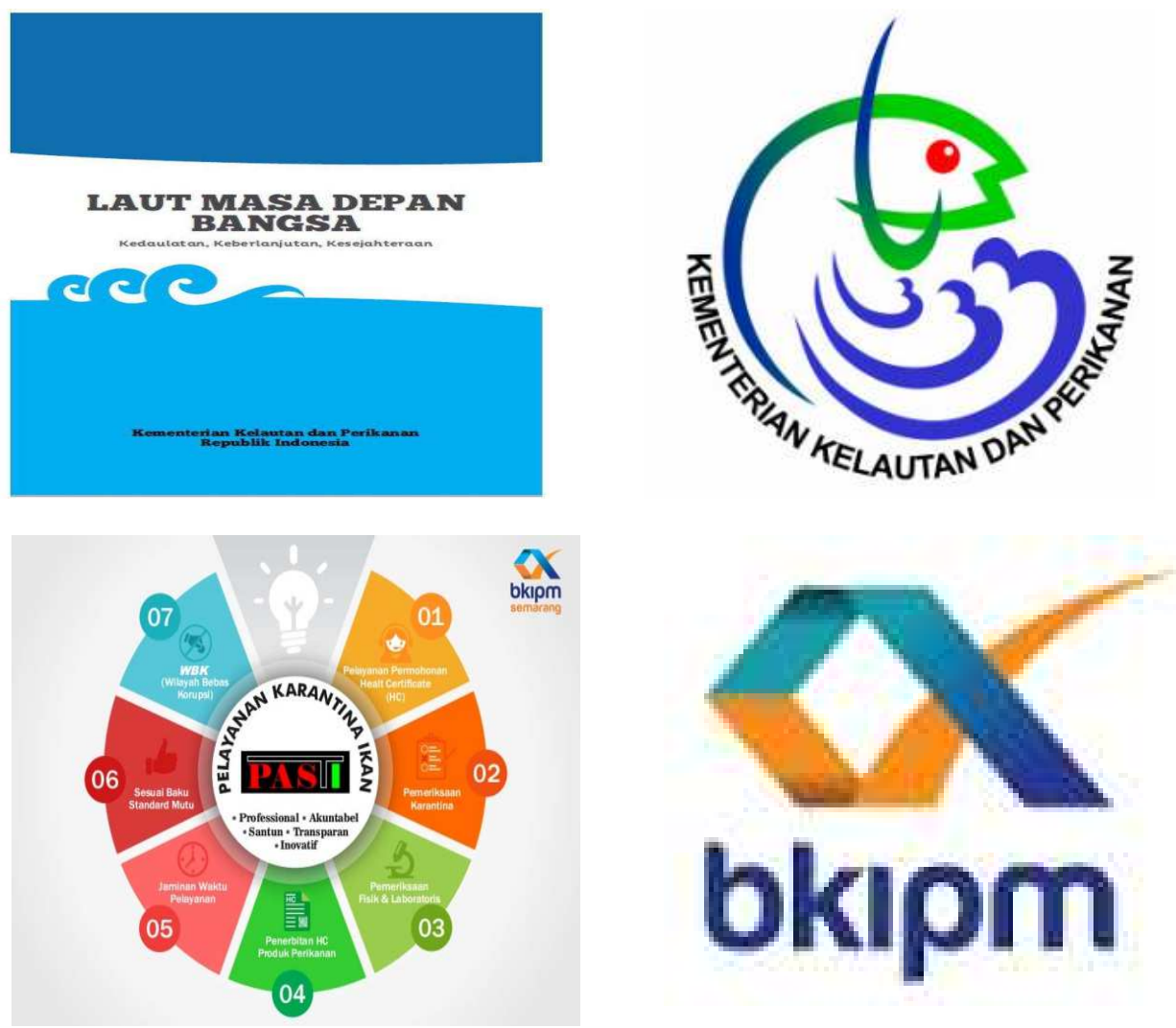

The selection of interesting languages is a means of the work unit of the Ministry of Maritime and Fisheries Affairs of the Republic of Indonesia to convey the purpose and as the spirit of building nation with attractive language that attracts people's attention. It was done because slogan can be defined as a set of words or sentences which are relatively short which is generally interesting and easy to remember by the midst of the community. In the slogan above there are two slogans from the Ministry of Maritime and Fisheries Affairsand the Semarang Fish Quarantine Service Center. Both of them have the same inherent slogan, namely the "Laut Masa Depan Bangsa" -Sea is the Future of Nation, and "PASTI". However, when viewed from the language construct, the Ministry of Maritime and Fisheries Affairsof the Republic of Indonesia used one sentence, while the Semarang Fish Quarantine Center used one word "PASTI". PASTI is an abbreviation of Profesional, Akuntabel, Santun, Transparan, dan Inovatif (professional, accountable, polite, transparent, and innovative). 
Thus, it is a brand that can be linked to certain characteristics which are the same as visualization of logos and slogans introduced to the public[11].

The blue color in the physical form of the slogans in the Ministry of Maritime Affairs and Fisheries Affairs of the Republic of Indonesia depicts the color of the Indonesian sea and symbolizes competence, consistency, and professionalism. This ministry has a high degree of competence namely Susi Pudjiastuti as a professional in the field of marine and fisheries. In fact, Minister Susi often sinks foreign ships that are stealing fish in the seas of Indonesia. This proves that this agency is very competent. This institution also has a high level of consistency to care for and develop Indonesia's marine potential. The professional aspects in the Ministry of Maritime Affairs and Fisheries Affairs of the Republic of Indonesia are also seen in the management of marine potential which is grouped into several management areas such as those held in Semarang, Padang, Kalimantan, to Papua.

The visualization of the slogan in the Ministry of Maritime Affairs and Fisheries Affairs of the Republic of Indonesia also means that the future of the Indonesian people also depends on the sea and the contents in it. This ministry always creates a good synergy about the use of the sea and fish. The slogans produced also follow the needs and developments of the dynamic times[12]. The slogan made also has a goal that is relevant to the maximum empowerment of the sea, despite the theft of large numbers of fish. Therefore, with the launching of these passionate slogans, it is hoped that the public and employees of the Ministry of Maritime and Fisheries Affairs of the Republic of Indonesia will be able to implement their slogan messages properly and have high integrity for the benefit of the nation[13].

\section{Conclussion}

The Ministry of Maritime Affairs and Fisheries has various logos and slogans. The logo and slogan have a memorable philosophy and meaning for the employees of this ministry and the people in Indonesia. the meaning in this ministry logo is dominated by professional aspects and high competence. This aspect is symbolized in blue which dominates the logos in this ministry. in addition, this ministry also has an interesting language aspect. languages in the logo are tangible slogans which can be used as a basis for implementing the activities of the ministry's programs. the program includes things that can make the sea and fish a source of life in Indonesia. consistent marine management and punishment for fish thieves are also represented by the words that become slogans in the logos in each work unit under the auspices of The Ministry of Maritime and Fisheries Affairs of the Republic of Indonesia.

\section{Acknowledgement}

The author thanks to The Ministry of Maritime Affairs and Fisheries and Universitas Sebelas Maret for providing teh author with good opportunities and support to be able to study and study in postgraduate programs.

\section{REFERENCES}

[1]. Vera, N. Semiotika dalam Riset Komunikasi. Bogor: Penerbit Ghalia. 2014

[2]. Yuliansyah, A. T., \& Hirajima, T. Efficacy of Hydrothermal Treatment for Production of Solid fuel from oil palm wastes. Resource Management for Sustainable Agriculture. 2012.

[3]. Wiyadi, C. D., Bangsa, P. G., \& Christianna, A. Analisis Visualisasi Iklan Televisi Xl Prioritas Versi" Re-imagined". Jurnal DKV Adiwarna, 1(8), p.11. 2016

[4]. Bolinger, D. Aspects of Language. New York: Horkourt Brace. 1975. 
[5]. Kassens-Noor, E. Twitter As a Teaching Practice to Enhance Active and Informal Learning in Higher Education: The Case Of Sustainable Tweets. Active Learning in Higher Education, 13(1), pp.9-21. 2012.

[6]. Moleong, Lexy J. Metode Penelitian Kualitatif. Bandung: PT Remaja Rosdakarya. 2010.

[7]. Herawati, A. The Cooperative Principle: Is Grice's Theory Suitable To Indonesian Language Culture. Jurnal Lingua Cultura. vol 7. (1). Pp. 43-48. 2013.

[8]. A Devilito, R., Wardani, N. E., \& Saddhono, K. Character Education Through Its Depiction of Life in The Novel Entitled Kerumunan Terakhir By Okky Madasari (Psychologycal Analysis of Literature). Lingua Didaktika: Jurnal Bahasa dan Pembelajaran Bahasa, 11(2), 185-194. 2017.

[9]. Listya, A. Bukan Sekedar Hiasan: Gaya Grafis Khas Sebagai Identitas Visual Korporat. Jurnal Desain, 3(02), 107-117. 2016.

[10]. Fitri Yanti, D., Zubaidah, M. S., \& San Ahdi, M. S. Perancangan Visual Branding Kota Sawahlunto. DEKAVE: Jurnal Desain Komunikasi Visual, 4(1). 2017.

[11]. Labrecque, Lauren I., \& Milne, George R. "Exciting Red and Competent Blue: the Importance of Color in Marketing", Journal of the Academy of Marketing Science, 40 (5), pp.711-727. 2012.

[12]. Halim, B. C. Pengaruh Brand Identity Terhadap Timbulnya Brand Preference dan Repurchase Intention Pada Merek Toyota. Jurnal Strategi Pemasaran, 2(1), pp.1-11. 2014.

[13]. Pudjiastuti, S. "Mengembangkan Kelautan dan Gemar Makan Ikan" taken from www.kkp.go.id was accesed 21 July 2019. 